\title{
STRUCTURES OF STEROIDS ISOLATED FROM THE ORGANIC MATTER OF BULGARIAN OIL SHALES
}

\author{
G. KOVATSEV. BULGAARIA POLEVKIVI ORGAANILISEST AINEST ERALDATUD STEROIDIDE \\ STRUKTUURID \\ Г. КОВАЧЕВ. СТРУКТУРЫ СТЕРОИДОВ, ВЫДЕЛЕННЫХ ИЗ ОРГАНИЧЕСКОГО ВЕЩЕСТВА \\ БОЛГАРСКОГО ГОРЮЧЕГО СЛАНЦА
}

(Presented by I. Klesment)

In connection with the prospecting for oil shales in Bulgaria and their utilization, we investigated the steroid structures in the oil shales. The hydrocarbon fraction containing steroids has been analyzed by gas chromatography and mass spectrometry. Cholestane, ergostane and sitostane have been identified. This paper presents the results of the analysis of the steroid hydrocarbons.

\section{Experimental Part}

The oil shale samples were taken from the gallery of Yaroslavtsy near the village of Krassava from following depths: N $7308-29 \mathrm{~m}, \mathrm{~N} 7309$ - $32 \mathrm{~m}, \mathrm{~N} 7314-40 \mathrm{~m}$, $\mathrm{N} 7315$ - $46 \mathrm{~m}$ and two samples from the borehole N 24 from depths of 434 and $438 \mathrm{~m}$.

Steroid hydrocarbons were separated using extraction with benzene/ethanol in a 3 to 1 ratio, column chromatography on $\mathrm{Al}_{2} \mathrm{O}_{3}$ (hexane elution), urea clathrate method following a procedure described earlier $\left[{ }^{1,2}\right]$ : The steroid hydrocarbons are concentrated in the so-called non-adducts fraction after treating the total hydrocarbons fraction of the hexane elution with urea.

Fig. 1. Gas chromatogram of the «non adducts» fraction.

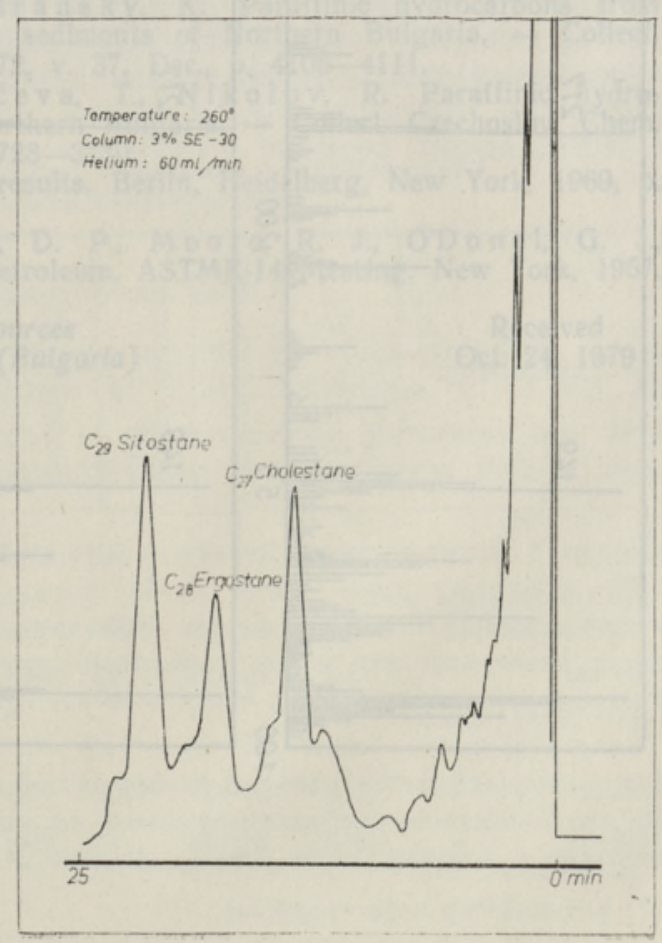




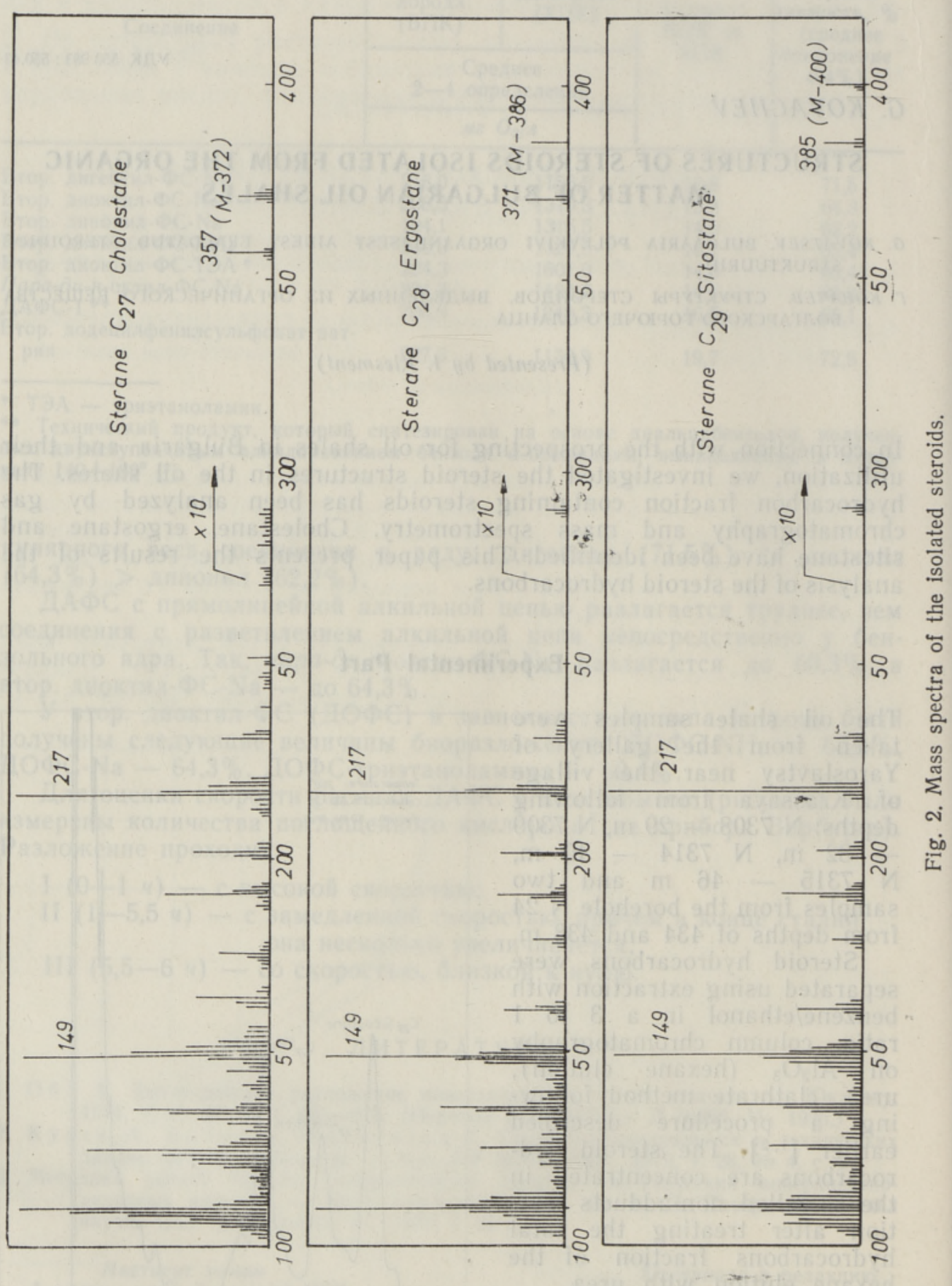


Gas chromatography was carried out on a Perkin Elmer chromatograph model F 17 provided with flame ionization detectors and a dual column system $(0,4 \times 150 \mathrm{~cm})$ containing $3 \%$ OV-17 on Chromosorb W-HP, $(80-100$ mesh). Sitostane was used as standard for a qualitative evaluation (Fig. 1).

Mass spectrometry was carried out on a combined gas chromatography - mass spectrometry apparatus LKB-2091 equipped with a minicomputer and PDP-11 processor.

\section{Results}

Using the combined gas chromatography - mass spectrometry method, the steroid structures - cholestane, ergostane, sitostane - have been identified. The study of the mass spectra and the typical fragmentation has shown that all signals of steroids are present in the spectra, mainly the

value 149 [N] $]^{+}, \mathrm{m} / \mathrm{e} 217\left[\mathrm{O}^{+}\right]$and also the values $M$

minus 15 (357, 371 and 385) for all the steroids (Fig. 2). On the basis of the spectra obtained and their similarity with the spectra published earlier $[3,4]$, we have been able to identify these hydrocarbons structures as steroids in the following order: $\mathrm{C}_{27}$ - cholestane, $\mathrm{C}_{28}$ - ergostane and $\mathrm{C}_{29}$ - sitostane.

\section{REFERENCES}

1. Kovačev, G., Del ova, D., Stránský, K. Paraffinic hydrocarbons from Devonian, Triassic and Jurassic sediments of Northern Bulgaria. - Collect. Czechoslov. Chem. Commun., 1972, v. 37, Dec., p. 4106-4111.

2. Kovačev, G., Ubik, K., Mi nčeva, T., Nikolov, R. Paraffinic hydrocarbons from crude oil from Northern Bulgaria. - Collect. Czechoslov. Chem. Commun., 1975 , v. 40 , Dec., p. $3728-3730$.

3. Organic geochemistry. Methods and results. Berlin, Heidelberg, New York, 1969, p. $409-415$.

4. Schissler, D. O., Stevenson, D. P., Moore, R. J., O'Donel, G. J., Thorpe, E. E. Steranes in petroleum. ASTME-14 Meeting. New York, 1957.

Research Institute of Mineral Resources

Laboratory of Organic Geochemistry (Bulgaria)
Received

Oct. 24,1979 